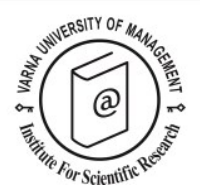

\title{
What makes scuba diving operations successful: The case of Portofino, Italy
}

\author{
Engelina du Plessis ${ }^{1 *}$ and Melville Saayman ${ }^{2}$
}

Received: 22/08/2016 Accepted: 12/12/2016

\begin{abstract}
1 Tourism, Research in Economic Environs and Society (TREES), North-West University, Private bag x6001, Potchefstroom, 2520, Republic of South Africa; Tel: +27 (0) 18299 1497; E-mail: Lindie.DuPlessis@nwu.ac.za 2 Tourism, Research in Economic Environs and Society (TREES), North-West University, Private bag x6001, Potchefstroom, 2520, Republic of South Africa; Tel: +27 (0) 18299 1810; E-mail: Melville.saayman@nwu.ac.za * Corresponding author
\end{abstract}

\begin{abstract}
The coastline of Portofino, Italy, a famous destination for the rich and famous, attracts thousands of visitors each year. Tourism product owners constitute a significant component of the competitive environment in this area in order to claim a piece of the tourism pie. For the local dive operators, the situation tends to be even more difficult when dealing with strict regulations concerning the marine protected area and a specific market. The identification of critical success factors could offer some insight into the management of these operations. In order to accomplish this, a qualitative research approach was followed by interviewing eight dive operators in the area of Portofino. It was clear that the critical success factor to manage a dive operation was unique to this area and differs from other tourism products by adopting a unique customer relations approach, an emphasis on safety, and the focus on providing a signature product. These results could assist managers of dive operations in identifying new opportunities in terms of management and sought out threats to the business.
\end{abstract}

(C) 2017 Varna University of Management. All rights reserved

Keywords: Portofino, dive operators, management, critical success factors.

Citation: Plessis, E., M. Saayman (2017) What makes scuba diving operations successful: The case of Portofino, Italy. European Journal of Tourism Research 17, pp. 164-176

\section{Introduction}

Scuba diving tourism, like many other forms of tourism, has witnessed unprecedented growth in competition from a supply side, which implies that more entrepreneurs are starting diving operations. This is especially evident at the diving sites in the marine protected areas at Portofino in Italy where approximately 20 diving operators are active. The marine protected area of the Portofino promontory (Map 1) extends for $13 \mathrm{~km}$ along the Italian coastline and is characterised by a rough coastline, a steep seabed, and high indices of biodiversity, both in its terrestrial and marine ecosystems. In preventing the intense urban and tourism development, a terrestrial protected area was established in 1935, and in 1998 the national government created a marine protected area (Salmona and Verardi, 2001). Presently, this area is known to host tourists by providing 
activities such as recreational boating, scuba diving and snorkelling to name but a few, making this a highly competitive tourism environment.

The operators share approximately $60 \quad 000$ divers every year who descend on the marine protected area (see Map 1). This implies that in order for the operators to survive, quality service is of the utmost importance, which reiterates the notion by Marais and Saayman (2011) that in order for businesses to survive in a very competitive environment, effective management is of utmost importance. These researchers also stress that continued evaluation of service levels is important in order to satisfy tourists or in this case scuba divers (Williams and Soutar, 2009; O'Niell, Williams, MacCarthy and Groves, 2000 and McCarthy, O'Niell and Williams, 2006). In addition, it is also very important to understand how these entrepreneurs operate and remain financially viable. The latter forms the basis of this research which seeks to address the question: what makes a scuba diving operation successful in such a very competitive environment? Therefore what are the critical success factors (CSF's) in managing diving operations? The purpose of this paper is therefore to identify the critical success factors of managing a diving operation. Answers to this can be very useful to diving operators across the globe of which there are in excess of 10000 operators serving in excess of 6 million divers as well as those potential entrepreneurs who are considering starting such a business (http://aboututila.com/Scubalnfo/Scuba-DivingCertification-Agencies.htm).

\section{Literature review}

Identifying critical or key success factors have been on the agenda of several tourism researchers since the 1990s, although it was first applied in the 1960s in the field of Information Systems (IS). Recent research stressed the importance of critical success factors as an element of strategic management (Black, 1990; Nieh and Pong, 2012). Further to this, it also helps with positioning a business (Jones, Singh and Hsiung, 2015), defines and focuses management responsibilities and efforts (Park, 1990), and assists with the efficient allocation of resources (Freeman and Thomlinson, 2014), ensuring quality management (Burger and Saayman, 2009), satisfying customers, increasing business success (Ferreira and Fernandes, 2015), enhancing visitor experiences (Caralli, Stevens, Willke and Wilson, 2004; Erasmus, Kruger and Saayman, 2012), increasing revenue (Freeman and Thomlinson, 2014), achieving higher return in equity (Hua, Chan and Mao, 2009), growth and development (Lin and $\mathrm{Fu}, 2012$ ), increased opportunities (Freeman and Thomlinson,

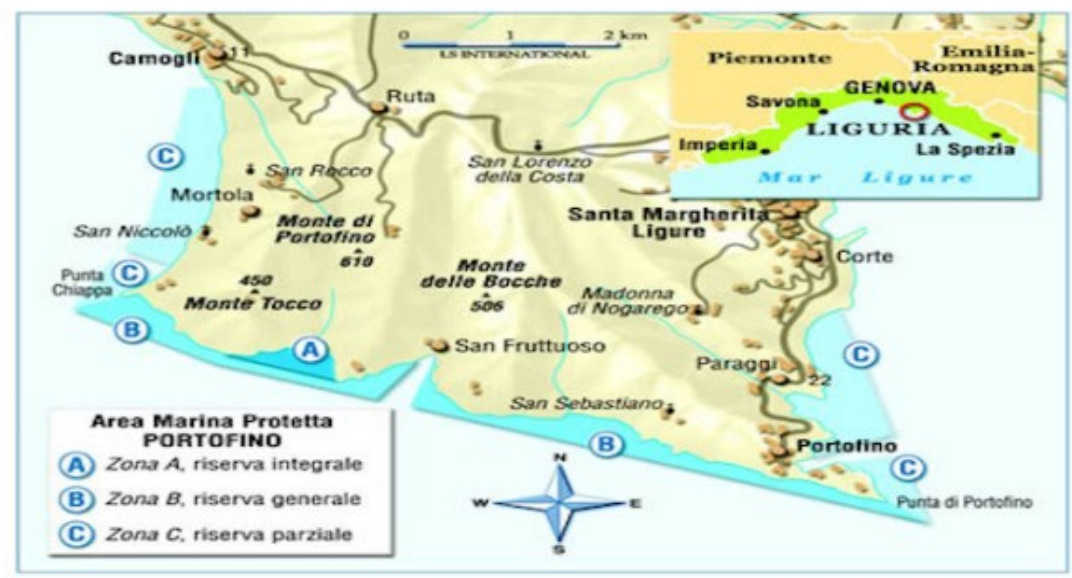

Map 1. Portofino Marine Protected area

Source: http://portofinonews.it/area-marina-portofino-tesserino-obbligatorio-la-pesca-sportiva/ 
2014), gaining competitive advantage (Lin and Fu, 2012, Nieh and Pong, 2012) and increasing sustainability (Nieh and Pong, 2012 and Freeman and Thomlinson, 2014). These studies highlight the importance and benefits of identifying critical success factors; but what are critical success factors? In layman's terms, one can define key or critical success factors as a few things that must go right in order to ensure success (Brotherton, 2004a, O'Brien, 2002). Critical success factors are therefore the limited areas, strategic elements or variables that require attention due to their importance and when properly sustained, maintained and managed can exert a significant impact on the success of an event or organisation and could differentiate between profit and loss (Bullen and Rockart 1986; Leidecker and Bruno, 1987; Williams and Saayman, 2013). Engelbrecht, Kruger and Saayman (2014) state that there should be between three and ten factors. It is furthermore important to note that ChoonChiang (1998) as well as Engelbrecht et al. (2014) concluded that critical success factors differ from business to business or sector to sector.

Whilst several studies focusing on critical success factors have been conducted in tourism, the literature review revealed that none of these have been carried out in the field of scuba diving tourism. Scuba diving tourism can be seen as travel with the primary reason to participate actively or passively in scuba diving activities. These may include scuba diving itself, attending shows and exhibitions and other scuba events for example. To this extent, Wilks and Davis (2000) state that every year more than a million scuba divers travel to the Great Barrier Reef in Australia and they spent in access of 10.3 million Australia dollars. Therefore it is one case where the tourism industry depends on scuba. There are many other diving spots across the globe that regard scuba diving tourism as the livelihood of many countries. Which stresses the importance of this type of research. Wilks and Davis (2009) go further to state that 243 dive operators are active in the Great Barrier Reef. Dimmock and Musa (2015) add that with the increase in demand for scuba diving the businesses that supports scuba diving tourism have become important sectors. In addition these scuba divers are driven by a desire to see and experience the marine environment. Tabata already indicated in 1992 that scuba diving tourism is an important and growing component of national and international travel globally. O'Niell et al. (2000) however confirm that little research concerning dive operators have been done. Table 1 below indicates that most of the studies have been conducted in the accommodation sector.

The most frequently found critical success factors identified in the literature review (Table 1) from a supply vantage were mentioned in order of importance, namely human resources, effective financial management, customer related approach, quality services, quality facilities, being effective, good marketing, effective systems and hygiene.

\section{Methodology}

In the literature review, it is also noteworthy that these critical success factors can be determined by either focusing on the demand or supply side depending on the focus of the research. This study, however, focused on the supply side. From a methodology point of view, the critical success factors could also be determined by means of a quantitative or qualitative approach, or a combination thereof. Most of the studies listed in Table 1 were conducted by applying a quantitative approach. The study under investigation applied a qualitative approach since the total population is relatively small compared to some of the studies found in Table 1, especially when one considers studies focusing on hotels and guesthouses (accommodation sector). It was also felt that a qualitative approach would provide richer data that is more appropriate for this research. In order to determine the critical success factors of dive operators / owners in the marine protected areas of Portofino, a qualitative survey of seven interviews were conducted with operators / owners who are also the managers of the respective businesses during November 2015. There are 20 dive operators based in the area under investigation from which we selected eight by means of random sampling. One person indicated that he was too busy; hence the remaining (7) were willing and available to participate in the study. Structured interviews 


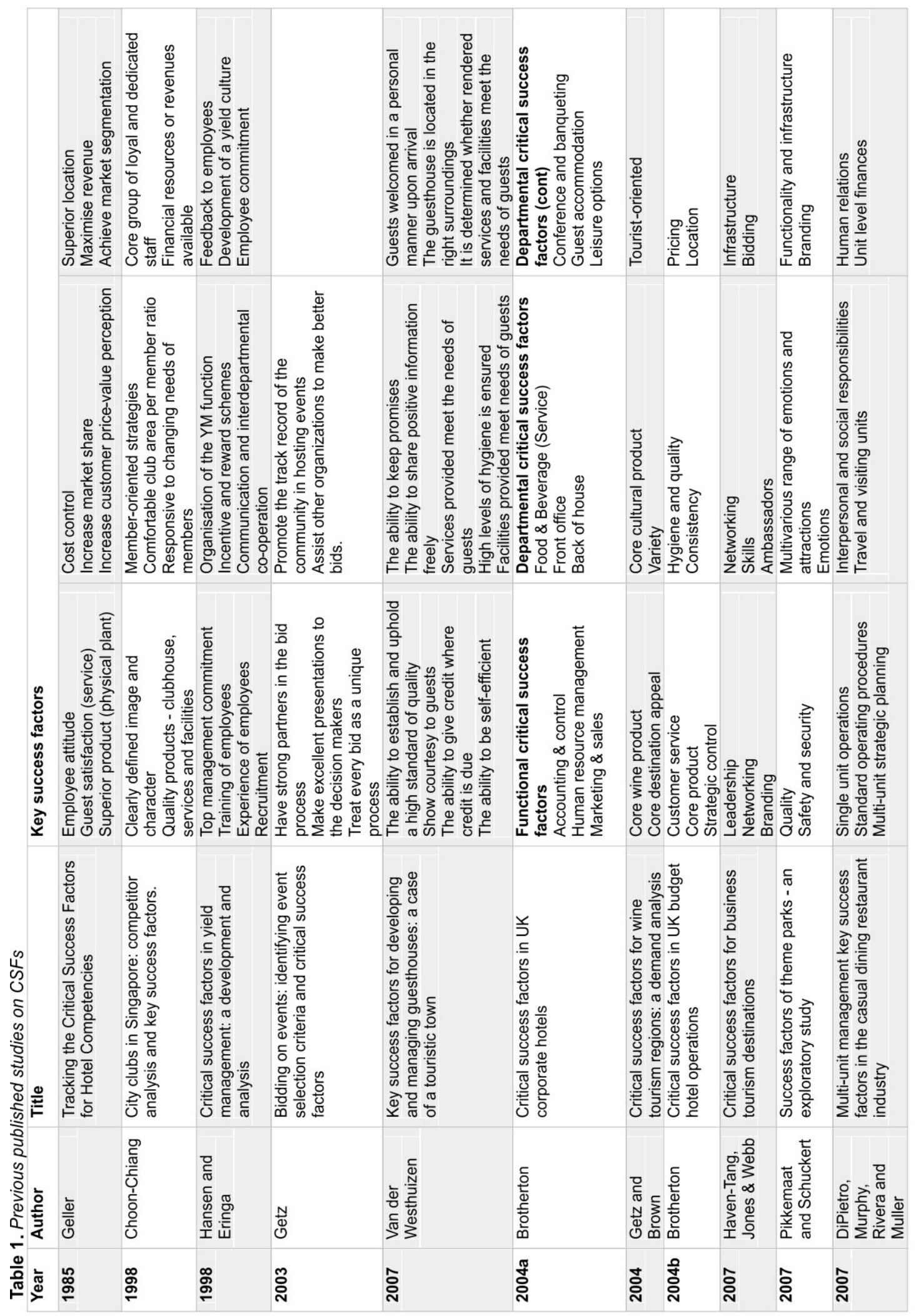



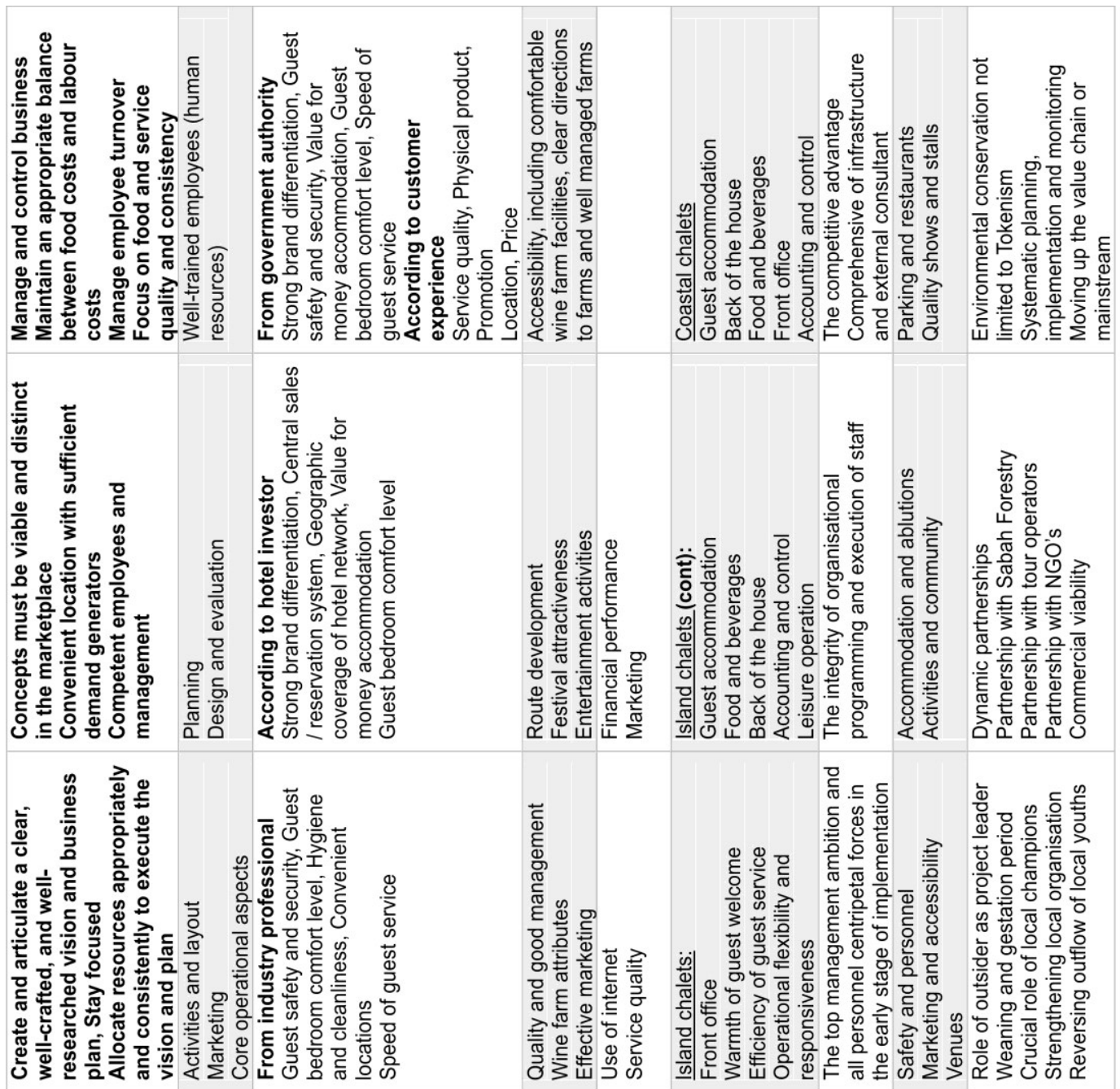

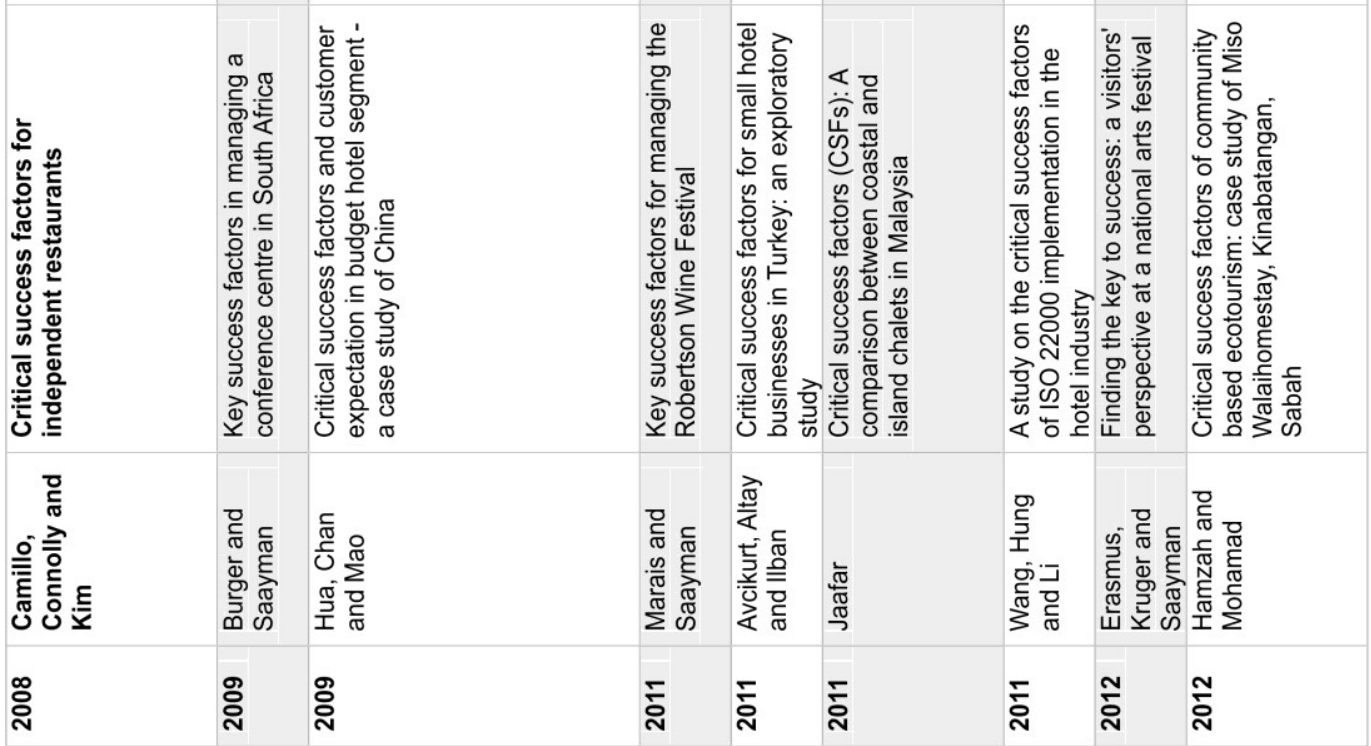




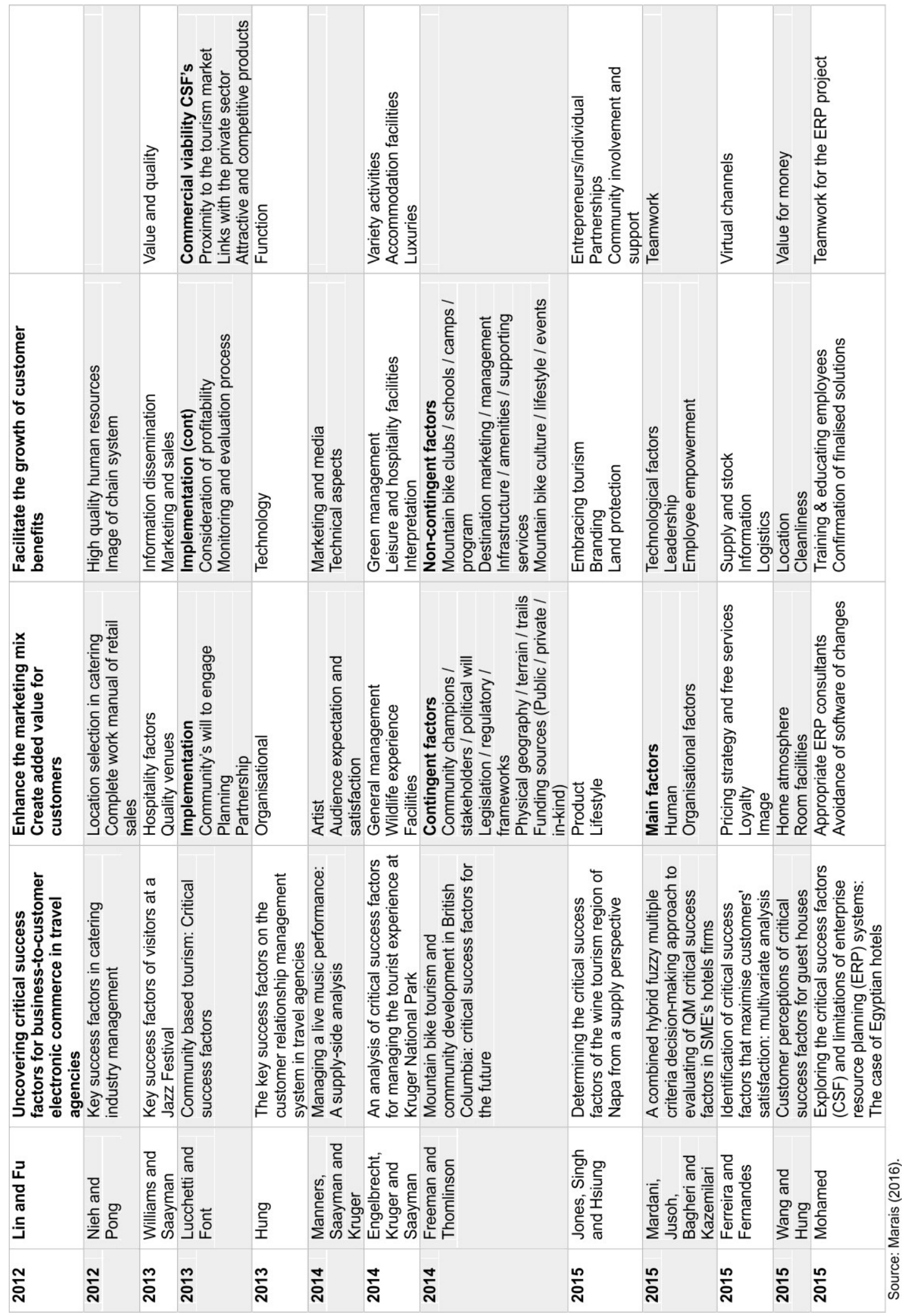


within the qualitative research method are usually adopted in multiple case studies to ensure structure and that the questions are detailed and developed in advance, for example, as in a research survey (Nieuwenhuis, 2008, p. 87). The first five questions were designed to obtain a general but basic profile of each respondent and business, followed by questions designed to gain the respondents' opinions on CSF of dive operations management. Based on the responses of the respondents, follow-up questions were formulated respectively. Interviews were audiotaped, transcribed, and subsequently further analysed by the authors.

Interviews were scheduled in advance with the seven respondents who have dive permits for the marine protected area of Portofino and whose operations were based or located in the villages of Santa Margherita, Camogli, Genova and Rapallo.

Based on the literature review as indicated in Table 1, interview guidelines (a questionnaire), consisting of and of three sections, were compiled:

- Section A consisted of the demographic profile, which focused mainly on the operational aspects of the business and included questions relating to the years in operation, number of boats, permanent staff and contract workers. This information gives an indication of the size of the business operations.

- Section B focused on the key success factors of managing a dive operation. Questions referred to factors that could enhance a dive operation and the challenges faced. What makes their businesses a success and what makes it sustainable?

- Section C focused on obtaining information on their marketing strategies, but was not deemed necessary for this article since it extended beyond the CSFs and looked at who are they marketing to.

Collected data were transcribed into text and presented in narrative form, after which it was analysed by using Creswell's six steps in data analysis and interpretation. The six steps are (Creswell, 2009):

1. Organise and prepare the data. This included organising the data as well as the 170 transcriptions of the recorded interviews and preparing it for analysis. Research was also conducted by employing content analysis utilising the search results of numerous scholarly journals that have conducted research on CSFs in the tourism industry in order to obtain a background regarding the similarities or gaps between the different approaches and perceptions towards CSFs.

2. Read through all the data. During this step, the data was read through several times in order to obtain a general sense of the information.

3. Begin a detailed analysis with a coding process. The data with regard to critical success factors for managing dive operations were coded in order to identify the important aspects. Thereafter, a recode process was followed by the co-author in order to ensure trustworthiness. The results were then compared with one another in order to gain an overall perspective.

4. Use the coding process to generate a description of the setting or people as well as categories or themes for analysis. The various codes were then divided into categories, where after themes were allocated to each category. The allocated themes appear as the major findings in the results and were used to create headings in the findings section of this study.

5. Advance how the description and themes will be represented in the qualitative narrative.

A discussion followed mentioning the chronology of the importance of the themes identified. This step conveys descriptive information about each given theme and the information identified by each respondent.

6. A final step in data analysis involves interpreting or making meaning of the data. Lastly, personal interpretation and understanding were formulated with regard to the results gained from this research.

Trustworthiness is an indication of methodological soundness and adequacy (Holloway and Wheeler, 2010). For this research, trustworthiness was illustrated by means of coding and recoding the data. The data were verified by sending it back to the dive operators via e-mail for their final input and verification.

\section{Results}

The results based on the survey that was conducted follows. 
Table 2: Demographic profiles of diving operations

\begin{tabular}{|c|c|c|c|c|c|c|c|}
\hline & $\begin{array}{c}\text { Respondent } \\
1\end{array}$ & $\begin{array}{c}\text { Respondent } \\
2\end{array}$ & $\begin{array}{c}\text { Respondent } \\
3\end{array}$ & $\begin{array}{c}\text { Respondent } \\
4\end{array}$ & $\begin{array}{l}\text { Respon- } \\
\text { dent } 5\end{array}$ & $\begin{array}{c}\text { Respondent } \\
6\end{array}$ & $\begin{array}{c}\text { Respondent } \\
7\end{array}$ \\
\hline $\begin{array}{l}\text { Years in } \\
\text { operation }\end{array}$ & 5 years & $\begin{array}{l}\text { More than } 10 \\
\text { years in the } \\
\text { business }\end{array}$ & $\begin{array}{l}\text { More than } 10 \\
\text { years in the } \\
\text { business }\end{array}$ & $\begin{array}{l}\text { More than } 10 \\
\text { years in the } \\
\text { business }\end{array}$ & 5 years & $\begin{array}{l}\text { More than } 10 \\
\text { years in the } \\
\text { business }\end{array}$ & 20 years \\
\hline Boats & 3 boats & 2 boats & 2 boats & 2 boats & 2 boats & 1 boats & 4 boats \\
\hline $\begin{array}{l}\text { Permanent } \\
\text { staff }\end{array}$ & $\begin{array}{l}4 \\
\text { Perma- } \\
\text { nent staff }\end{array}$ & $\begin{array}{l}2 \text { permanent } \\
\text { staff }\end{array}$ & $\begin{array}{l}2 \text { permanent } \\
\text { staff }\end{array}$ & $\begin{array}{l}\text { 5-6 } \\
\text { permanent } \\
\text { staff }\end{array}$ & & Just owners & $\begin{array}{l}10-12 \text { people } \\
\text { with different } \\
\text { roles }\end{array}$ \\
\hline $\begin{array}{l}\text { Contract } \\
\text { workers }\end{array}$ & 6 & None & In summer 6 & $\begin{array}{l}\text { Friends help } \\
\text { over } \\
\text { weekends }\end{array}$ & $\begin{array}{l}4-5 \\
\text { people }\end{array}$ & $\begin{array}{l}\text { 3-4 over } \\
\text { weekends / In } \\
\text { season 1-2 }\end{array}$ & $\begin{array}{l}\text { 3-4 over } \\
\text { weekends / } \\
\text { In season } \\
1-2\end{array}$ \\
\hline
\end{tabular}

\section{The demographics of the dive operators}

Section A was developed to capture the information regarding the demographic details of the dive operation and included the following questions as presented in Table 2:

Question one (Q1): How many years have you been in operation as a dive operator? (This was aimed at establishing the trustworthiness of the opinion of the managers or owners to provide answers that were supported by experience). Four of the operators had been in the diving business for more than 10 years. Two had been in the business for the last 5 years and one respondent had been a dive operator for more than 20 years.

Question two (Q2): How many boats do you have in operation? The majority of the dive operators have an average of two boats indicating the size of the business if one considered the cost of docking these boats and the maintenance thereof. It is very expensive to maintain a boat in Portofino as well as to acquire a permit for operating in the marine protected area.

Question three (Q3): How many staff do you employ? It is evident in Table 2 that operators adopt different approaches to human resource management and differ because of the size of operations, cost of employment, number of boats and seasonality to name only the common reasons mentioned by the operators. Based on these reasons, businesses can be classified as small enterprises.

Question four (Q4): To what extent do you employ contract workers? Answers to this question give an indication of the demand for the diving services offered by the respective diving operators. Most of the respondents do employ contract workers during divers' high season in particular. It was noted by the researchers that owners were wary about employing just anyone to help them due to the personal nature of the operator/diver relationship and the strong emphasis placed on the safety and quality experience.

It was clear from the interviews with these managers that they differ in personality, business approach and marketing strategies. It was, however, noteworthy how their personalities were portrayed in their manner of conducting their business. Some of the operators are extroverts and are more focused on the social aspect of the experience whilst the others are more focused on the diving experience and service delivery portraying a different personality approach. This observation contributes to this study by highlighting that personality plays an important role in the perception towards the CSFs of a business.

\section{Results of the key success factors}

Section B of the questionnaire focused on the main objective of this study, that is, to determine the critical success factors.

Question five (Q5): In your opinion, what are the key success factors in managing a diving operation in the area of Portofino? Referring to the fourth step of Creswell's (2009) guidelines, the various factors that were mentioned by the owners were categorised and allocated to themes. 
Based on the data, the authors identified six themes that captured the critical success factors. These themes / factors are supported by literature as indicated next to each factor. The six themes / factors, not presented in any specific order of importance, are: Customer relations (Brotherton, 2004(a); Ferreira and Fernandes, 2015; Geller, 1985; Lin and Fu, 2012; Marais and Saayman, 2011; Van der Westhuizen, 2003; MacCarthy et al., 2006); Location (Brotherton, 2004(a); Camillo et al., 2008; Nieh and Pong, 2012; Wang and Hung, 2015); Effective operations (Brotherton, 2004(b); Burger \& Saayman, 2009; DiPietro et al., 2007; Hung, 2013; Pikkemaat and Schuckert, 2007; Jaafar, 2011; Mardani et al., 2015; Wilks and Davis, 2000); Quality products and services (Engelbrecht et al., 2014; Geller, 1985; Getz and Brown, 2006; Williams and Soutar, 2009); Resources (Avcikurt et al., 2011; Choon-Chiang, 1998; Li et al., 2006; Wang et al., 2011); and Networks (Getz, 2003; Haven-Tang, Jones and Webb, 2007; Hamzah and Mohamad, 2012; Hua et al., 2009; Lucchetti and Font, 2013 Mohamed, 2015; Ortgueira and Gomez-Selemeneva, 2011).

Theme or factor 1: Customer relations

Within the theme or factor of customer relations, constructs such as loyal customers, customer focus, customer database, relationship with customers and relationship marketing strategies were mentioned. Respondents 1, 2, 3, 4 and 5 highlighted the importance of customer focus as being very important to maintain a loyal relationship and all five respondents indicated a personal marketing approach with the divers, which includes personal telephone calls and e-mails to their customers. Although customer relations is a CSF that is also indicated in literature (Brotherton, 2004; Geller, 1985) as being very important, the current research differs in terms of the personal approach these managers enjoy with their clients. Respondents 2 and 5 indicated that the personal customer relations captured their marketing efforts, which would result in positive word of mouth marketing. Respondent 1 adds to this by highlighting the importance of a well-developed data base of divers. The latter was not found in the literature as a construct of CSFs. Respondents 6 and 7 indicated the importance of customer relationships as a tool to establish the needs of customers in order to attract more customers, not as the other four respondents who indicated that they apply personal customer relations to keep and sustain loyal divers.

\section{Theme or factor 2: Location}

The marine protected area of Portofino is viewed as a high demand destination for the rich and famous, and enthusiastic divers in particular. It is therefore no surprise that location was considered to be an important critical success factor by respondents 1,4 and 6 , the reasons being that Portofino is accessible from large cosmopolitan areas, and particular to respondents 1 and 6, the docking of the boat in is an advantage to the business. Location in the case of tourism destinations is viewed by various researchers as being an important CSF, but differs among products (Wang and Hung, 2015). For example, the importance of budget and corporate hotels as indicated by Brotherton (2004); the advantage in terms of location for a wine festival (Marais and Saayman, 2011); location of arts festival (Erasmus et al., 2012)] just to name but a few. These results differ from previous studies in the sense that the uniqueness of this diving spot and the advantage of the location of the docking of the boat exerts a great impact on the visibility of the business to potential customers, financial considerations and accessibility to the primary product, namely diving.

\section{Theme or factor 3: Effective business operations}

Literature indicates business operations as a very important CSF (Brotherton, 2004(a\&b); Burger and Saayman, 2009; DiPietro et al., 2007; Jaafar, 2011; Hung, 2013; Mardani et al., 2015; Pikkemaat and Schuckert, 2007;) which includes constructs such as safety and security (Respondent 3 agrees with this), strategic control, hygiene, quality, pricing and organisational support, to name a few. In this case study, respondents 1 and 3 indicated that the management of the administration and finances were outsourced to other companies as constructs of this particular CSF of the business. The said functions were outsourced so as to enable them to primarily focus on the 
divers. Respondent 1 also indicated that Competitive prices are an important construct, although they have a very small margin from which to offer lower prices than the competitors. Respondent 4 focused on safety regulations as being important and Respondent 7 indicated that diversification of management tasks and products were the most important constructs contributing to effective business operations. It was highlighted by Respondent 7 that providing safety within the dive operations could ensure the competitive advantage of such a business.

Theme or factor 4: Quality Products and services

Quality products and services as a CSF is supported by the literature review (see Table 1 ), which is also applicable to the diving operations in Portofino. With the exception of Respondent 5, all the respondents indicated that the variety of quality of products and services in the form of workshops, events, fairs (Respondent 7) and different kinds of technical dives, training and an extraordinary experience, are factors contributing to this CSF. The researchers acknowledge the innovative skills of all these operators and the manner in which they seize the opportunities that are presented to them. For example, in the case of respondent 3 , being a marine biologist afforded him an advantage to offer a unique and specialised service his customers among whom was a scientist.

\section{Theme 5: Resources}

Managerial resources, often described in literature as a CSF, may include human resources (Hansen and Enringa, 1998; HavenTang et al., 2007), financial resources (Li et al, 2006), equipment (Mardani et al., 2015; Wang and Hung, 2015) and facilities (Engelbrecht et al., 2014). In the case of diving operations, all the aforementioned factors are constructs of the theme / CSF of resources, namely quality equipment and safety of equipment. Loyal and trained staff were also important to respondents 1, 5 and 7 whereas respondent 1 focused strongly on the financial resources of the diving operation. The variety, quality and condition of the equipment, including the boats, are very important and differ in terms of other tourism businesses, thus rendering these businesses unique.

\section{Theme 6: Networks}

Getz (2003) and various other researchers indicated networking as a CSF in tourism businesses, which implies networks with industry professionals, government authorities and investors (Hua et al., 2009); partnerships with operators, NGOs and commercial businesses (Hamzah and Mohamad, 2012) and links with the private sector (Lucchetti and Font, 2013). The diving operators are required to establish networks with government agencies, especially the marine protection authorities and marketing agencies. However, the CSF of networking for diving operators differs with the affiliations of the dive operators. For example, respondent 3 indicated that the network with universities exerted a positive impact on his business, especially since he enjoys a special relationship with universities that use his services for research purposes. He also has a permit to conduct research trips in restricted areas.

\section{Findings and recommendations}

The first finding highlights the six identified CSFs (Themes) of diving operations in the Portofino Marine protected area, namely customer relations, location, effective operations, quality products and services, resources and networks. Although similar themes / factors have been identified in literature, these factors are composed differently, comprising various constructs and are very sector related. The themes / factors identified in this study differ from those of other groups of CSFs, indicating the uniqueness of the diving operations. Critical success factors are sector specific as indicated by Engelbrecht et al. (2014) and the implication therefore is that focused research should be conducted in order to provide specific recommendations for businesses and entrepreneurs such as dive operators.

The second area highlights the unique CSF of customer relations that is very important to these operators. This approach has proven to be successful in the case of the dive operators of this specific area. The personal relationship ensures loyal customers, but can also have a 
negative effect in terms of time consumption. Dive operators who find themselves in such a situation could incorporate management of the operations into their customer relations.

The second finding reveals the close relationship that exists between the operators and customers (divers). This is different compared to other type of businesses in the tourism industry. The implication of this finding highlights the opportunity for operators to use personal relations to attract more visitors by offering special prices / packages to loyal divers in the form of "friends of the business" packages.

The third finding is based on the result that equipment and the safety aspect in a diving operation is paramount. Maintenance and safety for divers is of utmost importance and encourages loyalty to a specific operator because if they experience a safe dive environment (operation), they will most likely return. The implication is that a demand side survey would give insight into which other aspects are important to divers. This could be useful for operators in order to improve their services where possible.

The fourth finding reveals that the differentiation of products and services is strongly influenced by the experience, education and personality of the respective dive operators.

The last finding highlights the method of research applied in this study, a qualitative approach which was applied very successfully. However, this approach was even more successful because after the interviews, follow up e-mails summarising responses to each question were sent to each operator individually and they were asked to ensure the validity of the data as captured by the researchers. They were also afforded an opportunity to further clarify their answers if need be.

\section{Conclusions}

The goal of the study was to determine the critical success factors of diving operators in a very competitive environment in Portofino, Italy. It was clear from the interviews with the respondents that customer relations and 174 equipment (as part of the resources) are important. Developing personal relationships with customers, and ensuring safety and well maintained equipment for a variety of diving products and services from which to choose is important for managers of this region. The critical success factors for managing a diving operation clearly differ from those of other tourism enterprises.

This study contributes to the body of knowledge in terms of CSFs and highlight that these factors differ among products. The information gained from the results can give current operators and potentially new entrants insight into areas within the business that could improve their competitive advantage. This information could also form the basis on which to grow such a business and provide guidelines to entrepreneurs to start and sustain a diving operation. It is recommended that a study be conducted to determine the view from a demand side regarding the critical success factors of a dive operator.

It is however important to conduct the research including the perception of the divers to investigate the gaps and similarities in view of both the supply and demand sides.

\section{Acknowledgements}

This study was funded by the Green Bubbles RISE project, H2020-MSCA-RISE-2014. The project received funding from the European Union Horizon 2020 research and innovation programme under the Marie Sklodowska-Curie grant agreement No. 643712. This paper reflects only the views of the authors. The Research Executive Agency is not responsible for any use that may be made of the information it contains. The researchers would like to acknowledge the support of the dive centres who collaborated, and all the people who helped with this survey.

\section{References}

Avcikurt, C., Altay, H., \& Ilban, M. O. (2011). Critical success factors for small hotel businesses in Turkey: An exploratory study. Cornell Hospitality Quarterly, 52(2), 153164.

Black, J. (1990). The role and development of a manufacturing strategy. BPCS Business, Planning and Control System, 8/9, 29-31. 
Brotherton, B. (2004a). Critical success factors in UK budget hotel operations. International Journal of Operations \& Production Management, 24(9), 944-969.

Brotherton, B. (2004b). Critical success factors in UK corporate hotels. The Service Industries Journal, 24(3), 19-42.

Bullen, C. V., \& Rockart, J. F. (1986). A primer on critical success factors. In C. V. Bullen, J. F. Rockart, (Eds.) (1986) The rise of managerial computing: The best of the center for information system research. New York: Dow Jones-Irwin, 383-423.

Burger, E., \& Saayman, M. (2009). Key success factors in managing a conference centre in South Africa. South African Journal for Research in Sport, Physical Education and Recreation, 31(2), 15-28.

Camillo, A. A., Connolly, D. J., \& Kim, W. G. (2008). Critical success factors for independent restaurants. Cornell Hospitality Quarterly, 49(4), 364-380.

Caralli, R. A., Stevens, J. F., Willke, B. J., \& Wilson, W. R. (2004). The critical success factor method: establishing a foundation for enterprise security management. Pittsburgh, PA: Carnegie Mellon University, Software Engineering Institute.

Choon-Chiang, L. (1998). City clubs in Singapore: Competitor analysis and key success factors. Asia Pacific Journal of Tourism Research, 3(1), 55-63.

Creswell, J.W. (2009). Research design: qualitative, quantitative and mixed methods approach. 3rd ed. Thousand Oaks, Calif.: Sage.

Dimmock, K. \& Musa, G. (2015). The scuba diving tourism system: a framework for collaborative management and sustainability. Marine Policy, 54: 52-58.

DiPietro, R. B., Murphy, K. S., Rivera, M., \& Muller, C. C. (2007). Multi-unit management key success factors in the casual dining restaurant industry. International Journal of Contemporary Hospitality Management, 19(7), 524-536.

Engelbrecht, W. H., Kruger, M., \& Saayman, M. (2014). An analysis of critical success factors for managing the tourist experience at Kruger National Park. Tourism Review International, 17, 237-251.

Erasmus, J., Kruger, M., \& Saayman, M. (2012). Finding the key to success: A visitors' perspective at a national arts festival. Acta Commercii, 12(1), 150-172.

Ferreira, H. P., \& Fernandes, P. O. (2015). Identification of critical success factors that maximise customers' satisfaction: Multivariate analysis. Tourism \& Management Studies, 11(1), 164-172.

Freeman, R., \& Thomlinson, E. (2014). Mountain bike tourism and community development in British Columbia: Critical success factors for the future. Tourism Review International, 18, 9-22.

Geller, N. (1985). Tracking critical success factors for hotel companies. Cornell Hotel Restaurant Administration Quarterly, 25(4), 76-81.

Getz, D. (2003). Bidding on events: Identifying event selection criteria and critical success factors. Journal of Convention \& Exhibition Management, 5(2), 1-24.

Getz, D., \& Brown, G. (2006). Critical success factors for wine tourism regions: A demand analysis. Tourism Management, 27(1), 146158.

Hamzah, A., \& Mohamad, N. H. (2012). Critical success factors of community based ecotourism: Case study of Miso Walaihomestay, Kinabatangan, Sabah. The Malaysian Forester, 75(1), 27-40.

Hansen, C. N., \& Eringa, K. (1998). Critical success factors in yield management: A development and analysis. Progress in Tourism and Hospitality Research, 4, 229-244.

Haven-Tang, C., Jones, E., \& Webb, C. (2007). Critical success factors for business tourism destinations. Journal of Travel \& Tourism Marketing, 22(3/4), 109-120.

Holloway I. \& Wheeler S. (2010). Qualitative research in nursing and healthcare. Oxford, UK: Blackwell.

Hua, W., Chan, A., \& Mao, Z. (2009). Critical success factors and customer expectation in budget hotel segment - a case study of China. Journal of Quality Assurance in Hospitality \& Tourism, 10, 59-74.

Hung, C. (2013). The key success factors on the customer relationship management system in travel agencies. Pakistan Journal of Statistics, 29(5), 785-794.

Jaafar, M. (2011). Critical success factors (CSFs): A comparison between coastal and island chalets in Malaysia. Tourism, 59(4), 481-496. 
Jones, M. F., Singh, N., \& Hsiung, Y. (2015). Determining the critical success factors of the wine tourism region of Napa from a supply perspective. International Journal of Tourism Research, 7, 261-271.

Leidecker, J. K., \& Bruno, A. V. (1987). CSF analysis and the strategy development process. In D.T. Cleland, W. R. King, (Eds.) (1987) Strategic planning and management handbook. New York: Van Nostrand Reinhold Company, 333-351.

Lin, S., \& Fu, H. (2012). Uncovering critical success factors for business-to-customer electronic commerce in travel agencies. Journal of Travel \& Tourism Marketing, 29(6), 566-584.

Lucchetti, V. G., \& Font, X. (2013). Community based tourism: Critical success factors. The International Centre for Responsible Tourism, 27, 1-20.

MacCarthy, M., O'Niell, M. \& Williams, P. (2006). Customer satisfaction and scubadiving: some insights from the deep. The Service Industries Journal, 26(5):537-555.

Manners, B., Saayman, M., \& Kruger, M. (2014). Managing a live music performance: A supply-side analysis. Acta Commercii, 15(1), 1-11.

Marais, M., \& Saayman, M. (2011). Key success factors for managing the Robertson Wine Festival. Acta Academia,43(1),146-166.

Mardani, A., Jusoh, A., Bagheri, M. M., \& Kazemilari, M. (2015). A combined hybrid fuzzy multiple criteria decision-making approach to evaluating of QM critical success factors in SME's hotels firms. Prodecia - social and behavioral sciences, 172, 786-793.

Mohamed, L. M. (2015). Exploring the critical success factors (CSF) and limitations of enterprise resource planning (ERP) systems: The case of Egyptian hotels. Journal of Hospitality \& Management Tourism, 6(3), 17-29.

Nieh, F., \& Pong, C. (2012). Key success factors in catering industry management. Actual Problems of Economics, 4, 423-430.

Nieuwenhuis. J. (2008). Qualitative research designs and data gathering techniques. In: $\mathrm{K}$ Maree (ed). First steps in research. $2^{\text {nd }}$ edition. Pretoria: Van Schaik.

O'Brien, J. A. (2002). Management information systems-managing information technology in the E-business enterprise (5th ed.). New York: McGraw-Hill/Irwin.

O'Niell, M.A., Williams, P., MacCarthy, M. \& Groves, R. (2000). Diving into service quality - the dive operator perspective. Managing Service Quality; An International Journal, 10(3), 131-140.

Park, S. W. (1990). The characteristics and usage of computerized information systems in small apparel and textile companies. Unpublished $\mathrm{PhD}$ dissertation. Atlanta, Georgia: Georgia State University.

Pikkemaat, B., \& Schuckert, M. (2007). Success factors of theme parks - an exploratory study. Tourism, 55(2), 197-208.

Salmona, P., \& Verardi, D. (2001). The Marine protected area of Portofino, Italy: A difficult balance. Ocean \& Costal Management, 44(1-2), 39-60.

Tabata, R.S. (1992). Scuba diving holidays. In: CM Hall and B Weller (eds). Special interest tourism, Belhaven, New York, 171-184.

Van der Westhuizen, T. (2003). Key success factors for developing and managing a guesthouse. Unpublished master's thesis. Potchefstroom: North-West University.

Van der Westhuizen, T., \& Saayman, M. (2007). Key success factors for developing and managing guesthouses: a case of a touristic town. South African Journal for Research in Sport, Physical Education and Recreation, 29(2), 121-130.

Wang, F., Hung, C., \& Li, P.P. (2011). A study on the critical success factors of ISO 22000 implementation in the hotel industry. Pakistan Journal of Statistics, 27(5), 635-643.

Wang, S., \& Hung, K. (2015). Customer perceptions of critical success factors for guest houses. International Journal of Hospitality Management, 48, 92-101.

Wilks, J. \& Davis, R.J. (2000). Risk management for scuba diving operators on Australia's Great Barrier Reef. Tourism Management, 21, 591-599.

Williams, K., \& Saayman, M. (2013). Key success factors of visitors at a jazz festival. South African Journal for Research in Sport, Physical Education and Recreation, 35(1), 183-202.

Williams, P. \& Soutar, G.N. (2009). Value, satisfaction and behavioural intentions in an adventure tourism context. Annals of Tourism Research, 36(3), 413-438. 